\title{
Analysis of Critical Thinking Skill Based on The Difference of Gender at SMA Surakarta in Biology Subject
}

\author{
${ }^{1 s t}$ Ratih Intan Sari \\ Faculty of Teacher Training and \\ Education, Sebelas Maret \\ University \\ Surakarta, Indonesia \\ Ratihintansari76767@gmail.com
}

\author{
${ }^{2 n d}$ Puguh Karyanto \\ Faculty of Teacher Training and \\ Education, Sebelas Maret University \\ Surakarta, Indonesia \\ kariyani@yahoo.com
}

\author{
${ }^{3 r d}$ Muzzazinah \\ Faculty of Teacher Training and \\ Education, Sebelas Maret University \\ Surakarta, Indonesia \\ yayin_pbio@fkip.uns.ac.id
}

\begin{abstract}
The aim of this research was to analyze critical thinking skill of students at SMA Negeri in Surakarta district based on gender. It used facione criteria including interpretation, analysis, conclusion and self-regulation, this study gave information that women were better than men in critical thinking ability. The result of the result showed that average of all value critical thinking skill of women was higher of $60.6 \%$ that average value of critical thinking skill of men of $39.4 \%$. This study showed that gender significantly affected students' critical thinking skill. The conclusion of this research is that students' critical thinking ability is still in low category so it needs development in learning process to improve several indicators of critical thinking skill.
\end{abstract}

Keywords-component; Critical thinking ability, students' gender.

\section{INTRODUCTION}

Critical thinking is from of thinking that needs to develop for each student to improve education quality. As explained by Gedik h (2013) [5], because critical thinking is a needed competences in $21^{\text {st }}$ to students in facing many obstacle in their lives. Critical thinking enables an individual to become responsible citizen who gives contribution so society and he/she is not just consumptive.

Critical thinking is also important in learning process because it can exercise students to make a rational idea from many perspectives carefully critical thinking skill can be said Ennis (1996) [20], Sulistiyawati (2017) [15], Ratna Hidayah, Moh. Salim (2017)[13]. it is the same as Gedik [5]that a goal on education is by improving critical thinking skill. So critical thinking should become activity that must be developed and taught for each subject Cahyono (2017) [2]. Especially for natural science, it was taught critical thinking without realizing Schafersman (2008) [13]. Critical thinking is ability that had to be though.

Critical thinking skill of each students is different, even though the faced problem is the same. Many literature explained critical thinking skill based on gender. Leach dan Good (2011) showed that gender significantly affected the average of critical thinking skill [7]. Then Walsh \& Hardy (1999) also assumed that women had higher score in all aspect of critial thinking than men [15]. The result of the research by
Wilder and Powel (1989) showed that women had high memory [17]. In addition, women showed superiority in verbal skill. Whereas men were better in mathematics and natural science. The findings of the research were not inline with the result of N.-Y. Liu, Hsu, Hung, Wu, \& Pai( 2018) [8]. It showed that there was no difference significantly in critical thinking skill of students based on gender.

Based on the background above, it is conducted the research that aims to analyze critical thinking skill in students of SMA Negeri in Surakarta District based on gender.

\section{DATA/MATERIALS AND METHODS}

This research was a descriptive study using instruments developed based on aspects of critical thinking skills according to Facione [2] which include interpretation, analysis, evaluation, explanation, conclusion, and selfregulation. The sample in this study used the XI grader students of the Natural Sciences Program and 108 high school students 8 Surakarta were selected through purposive sampling technique. The data was obtained from the analysis of student answers. Data was obtained by coding each student's answers and printing each student's answers based on the assessment rubric. Based on the rubric, the researcher can determine whether students fulfilled each indicator of critical thinking skills or not in solving the problems contained in the problem. The method for calculating the percentage value was as follows:

Percentage Score $=\frac{\text { Obtained Score }}{\text { Maximum Score }} x 100 \%$

The percentage value of critical thinking skills obtained from calculations was then categorized based on table 1 . 
Table 1. Percentage Categories of Critical Thinking Skills

\begin{tabular}{ll} 
Interpretation (\%) & Category \\
\hline $81.25<\mathrm{X} \leq 100$ & Very high \\
$71.50<\mathrm{X} \leq 81.25$ & Height \\
$62.50<\mathrm{X} \leq 71.50$ & Medium \\
$43.75<\mathrm{X} \leq 62.50$ & Low \\
$0<\mathrm{X} \leq 43.75$ & Very low \\
\hline & \multicolumn{2}{c}{ Karim Adaptation }
\end{tabular}

\section{RESULTS AND DISCUSSION}

Based on test result analysis, it was obtained all data with average value of critical thinking skill of students in low category of $55 \%$. whereas for average value of critical thinking skill based on gender, value of women critical thinking skill was higher about $60.6 \%$ than men critical thinking skill value of $39.4 \%$. it was inline with the research by nur miftahul that critical thinking skill of women was better than men. It also explained that women (students) tent to get better in critical thinking skill than man.

If it was analyzed based on students' gende based on indicators of Facione (1990) in critical thinking skill as follow interpretation, analysis, evaluation, conclusion and selfregulation. So it was obtained difference in each gender as in table above.

Table 2. Category of critical thinking skill

\begin{tabular}{|l|l|l|l|}
\hline \multirow{2}{*}{ No } & \multicolumn{3}{|c|}{ Critical Thinking Skill } \\
\cline { 2 - 4 } & \multicolumn{1}{|c|}{ Indicator } & Women(\%) & Men(\%) \\
\hline 1 & interpretation & 77,3 & 75,0 \\
\hline 2 & analysis & 48,6 & 42,7 \\
\hline 3 & evaluation & 49,4 & 52,7 \\
\hline 4 & Explanation & 53,5 & 55,1 \\
\hline 5 & conclusion & 47,5 & 41,7 \\
\hline 6 & Self regulation & 58,2 & 54,7 \\
\hline
\end{tabular}

Based on the table, it can be seen that women have high critical thinking ability in indicators of interpretation, analysis, conclusion and self-regulation than men. Whereas men are better in indicators of evaluation and explanation [3].

\section{Interpretation}

In interpretation indicator of women was 77.3. It was higher than men of 75 . it was because women had ability to understand and express the meaning of experience, data, event, assessment, convention, belief, rule, procedure or criteria.

\section{Analysis}

For analysis indicator, women were higer of $48,6 \%$ than men of $42,7 \%$. It was because women had ability to identify and reveal accepted information in detail to be studied.

\section{Evaluation}

For evaluation indicator, men were higher of $52,7 \%$ than women of $49,4 \%$. it was because men in this category had ability in access credibility of question/representation and they were able to access logically the relation between question, description, question or concept.

\section{Explanation}

For explanation indicator, men are higher of $55,1 \%$ than women of $53,5 \%$. it is because men had skill in drawing conclusion reasonably and they gave strong reason over the answer from data, question, principle, prove, assessment, belief, opinion, concept, description, and other form of representation than women.

\section{Conclusion}

For conclusion indicator, women were higher of $47,5 \%$ than men of $41,7 \%$. It explained that women had ability in making conclusion based on elements of thinking ability logically and analytically.

\section{Self-regulation}

For Self-regulation indicator, women were higher of $58,2 \%$ than men of $54,7 \%$. In this case, women tent to have ability in managing themselves such as monitoring cognitive activity in their environment and reviewed the answer.

Based on explanation above, it can be concluded that average vale of women critical thinking skill is higher of $60.6 \%$ that men of $39.4 \%$. it shows that there is significant difference that affects critical thinking skill of women and men. Whereas for critical thinking skill average value for each indicator show that there is no significant difference between men and women [9][4]. critical thinking skill is low in indicator of evaluation, explanation, conclusion and selfregulation so it needs to develop. Interpretation indicator is categorized high. It means that students have ability in writing what is questioned correctly

\section{CONCLUSIONS}

The result shows that average critical thinking skill gives different result in each indicator and it is still in low category. Thus, teacher is expected to do learning activity that can develop students' critical thinking skill. The interpretation indicator is categorized high. There is no significant difference between women critical thinking skill and men.

\section{Acknowledgment}

Researchers would like to offer a gratitude to Mr. Puguh Karyanto, S.Si., M.Sc, Ph.D and Mrs. Dr. Muzzazinah, M.Sc, who has provided moral and material supports. In addition, 
researchers would also like to offer a gratitude to their friends who always give endless encouragement and support.

\section{References}

[1] Agung Pambudiono, Siti Zubaidah dan S M PERBEDAAN KEMAMPUAN BERPIKIR DAN HASIL BELAJAR BIOLOGI SISWA KELAS $X$ SMA NEGERI 7 MALANG BERDASARKAN JENDER DENGAN PENERAPAN STRATEGI JIGSAW 1-10

[2] Cahyono B 2017 Analisis Ketrampilan Berfikir Kritis Dalam Memecahkan Masalah Ditinjau Perbedaan Gender Aksioma 8 50-64

[3] Facione P A 1990 Critical Thinking: A Statement of Expert Consensus for Purposes of Educational Assessment and Instruction Executive Summary " The Delphi Report Calif. Acad. Press 423 1-19

[4] Fuad N M, Zubaidah S, Mahanal S and Suarsini E 2017 Improving Junior High Schools' Critical Thinking Skills Based on Test Three Different Models of Learning Int. J. Instr. 10 101-16

[5] Gedik H 2013 Social Studies Teacher Candidates' Critical Thinking Skills Procedia - Soc. Behav. Sci. 93 1020-4

[6] KHAIRUNNISA $\mathrm{R} \quad 2017 \quad$ ANALISIS METAKOGNISI SISWA DALAM PEMECAHAN MASALAH ARITMATIKA SOSIAL DITINJAU DARI PERBEDAAN GENDER

[7] Leach B T, Box E and Good D W 2011 Critical Thinking Skills as Related to Un iversity Students , Gender and Academic Discipline 1 100-6

[8] Liu N-Y, Hsu W-Y, Hung C-A, Wu P-L and Pai H-C 2018 The Effect of Gender Role Orientation on Student Nurses' Caring Behaviour and Critical
Thinking Int. J. Nurs. Stud.

[9] Myers B and Dyer J 2006 The Influence Of Student Learning Style On Critical Thinking Skill J. Agric. Educ. 47 43-52

[10] Peter A CRITICAL THINKING: A STATEMENT OF EXPFRT CONSENSUS I T FOR PURPOSES OF EDUCATIONAL ASSESSMENT AND INSTRUCTION

[11] Ramdiah S 2011 Seminar Nasional X Pendidikan Biologi FKIP UNS Jurnal 1-7

[12] Ratna Hidayah, Moh. Salim T S S 2017 CRITICAL THINKING SKILL: KONSEP DAN INIDIKATOR PENILAIAN 6 26-37

[13] Schafersman S D 2008 AN INTRODUCTION TO CRITICAL THINKING 1-13

[14] Sulistiyawati C A 2017 Kemampuan Berpikir Kritis dan Hasil Belajar Biologi Berdasarkan Perbedaan Gender Siswa 1 127-42

[15] Walsh C M and Hardy R C 1999 Dispositional differences in critical thinking related to gender and academic major. J. Nurs. Educ. 38 149-55

[16] Liu N, Hsu W, Hung C, Wu P and Pai H 2018 SC Int. J. Nurs. Stud.

[17] Wilder G Z and Powell K 1989 Sex Differences in Test Performance: a Survey of the Literature ETS Res. Rep. Ser. 1989 i-50

[18] Facione P a. 2011 Critical Thinking: What It Is and Why It Counts Insight Assess. 1-28

[19] Karim and Normaya 2015 Kemampuan Berpikir Kritis Siswa dalam Pembelajaran dalam Pembelajaran Matematika dengan Menggunakan Model Jucama di Sekolah Menengah Pertama Edu-Mat, 3

[20] Ennis R H 1996 Critical Thinking Dispositions: Their Nature and Assessability Informal Log. 18 165-82 